\title{
Perspectives
}

\section{History of Medicine in Eastern Europe: Sexual Medicine and Women's Reproductive Health in Czechoslovakia, Poland, and Hungary}

\author{
Kateřina Lišková \\ Associate Professor; Sociology Department, Faculty of Social Studies, \\ Masaryk University, Joštova 218/10, 602 oo Brno, Czech Republic \\ katerina@fss.muni.cz
}

\begin{abstract}
Specific developments in reproductive health occurred in Eastern Europe, especially in the second half of the twentieth century. During state socialism, it was experts, not social movements, who furthered the agenda of women's health and sexuality. New analyses from the region and written mostly by authors who speak the local languages attest to the wealth of histories, highlighting different timelines of reproductive health developments, the unexpected causes behind them, and the social actors and institutions which played decisive roles.
\end{abstract}

\section{Keywords}

Eastern Europe - sexual and reproductive health - twentieth century history - gender - expertise 


\section{Introduction}

There are many ways to write a history of Eastern Europe 'into' the broader field of the history of medicine. While the field might not be as institutionalized as elsewhere, scholarship on Eastern Europe possesses a unique power to change what we think we know about Europe or medical expertise in its historical development. Taking the recent history of medical approaches to reproduction and sexuality as an example, I will show that timelines differ from the ones known from 'established' historiographical accounts, and I will show how institutions (such as the state or the Church) shaped these histories in sometimes unexpected ways. Other surprising connections emerge, such as the one between women's fertility and their sexual pleasure. By 'recent,' I mean both recently written and the history of recent developments, i.e., occurring in the twentieth century. One familiar accent will remain: the connection between reproductive medicine on the one hand and gendered bodies and women's experiences on the other. Focusing on a specific strand of historiography in Poland, Czechoslovakia, and Hungary, I will illustrate the potential of bringing Eastern European perspectives to the project of a European history of medicine and health.

It is widely held that the recent history of reproduction has been marked by the invention of the birth control pill and by social movement struggles. ${ }^{1}$ However, the story of feminist and gay rebellions, flower power, and the pill is a very Western one. In postwar Eastern Europe, spontaneous civic action was not allowed, and the liberalization of reproduction occurred from above (more about that in the following section). Notably, while the West did not recognize fundamental reproductive rights, such as abortion, until the 1970s, most countries of the Eastern Bloc had already legalized abortion on demand by the mid-195os. When the pill was introduced in the West, terminating pregnancy became legally available in most Eastern countries. The combination of a relative lack of modern contraceptives with early and relatively unfettered access to abortion led to this procedure being used as the most frequent method of 'contraception.'

Abortion was first legalized in the Soviet Union in 1920, only to be banned by Stalin in 1936. In the postwar period, abortion was made available to women 'for social reasons,' i.e., reasons other than medical grounds that indicated a

1 Dagmar Herzog, Sexuality in Europe: A Twentieth-Century History (Cambridge-New York, 2011). 
pregnancy termination in specified cases. With the notable exception of East Germany and Albania, women in all socialist countries of Europe gained access to abortion in 1956 or $1957 .{ }^{2}$ While the main reasoning behind the legalization of abortion was to help women avoid economic or social hardship and to sustain their good reproductive health, the need for women to have a choice in their lives was also brought up by experts arguing in favor of legalization. Indeed, the expert voice was crucial in these debates, and the experts, primarily gynecologists, highlighted the emancipation of women as the driving force behind legalization. In practice, however, profiling women and sometimes downright discrimination against those seen as underserving was alive and well.

Within the Eastern-European region, the Polish approaches to contraception and abortion have been exceptionally well-researched. The postwar push towards pronatalism, especially in rural areas, ${ }^{3}$ included a battle against folk midwives who provided illegal abortions. ${ }^{4}$ Experts, namely demographers, argued for a 'rational' reproduction, as opposed to the 'natural' ways of the past. They lamented "the low civilization and cultural standards" of those bringing too many children into the world while hailing the more enlightened situation of postwar Poland joining the ranks of the developed countries. ${ }^{5}$ Historian Barbara Klich-Kluczewska argues that the ways of persuading people to fulfill state goals in family planning changed around 1970 from authoritarian to "soft methods based on negotiation and cooperation."6 In the early 197os, first family clinics opened, offering premarital advice and family therapies, and as the decade progressed, more psychologists came to the fore, introducing

2 For an overview, see Kateřina Lišková and Stanislav Holubec, "Women between the Public and Private Spheres," in The Routledge History Handbook of Central and Eastern Europe in the Twentieth Century, vol. 1, ed. Wlodzimierz Borodziej, Stanislav Holubec, and Joachim von Puttkamer (London, 2020), 183-234.

3 Barbara Klich-Kluczewska, "Making up for the Losses of War: Reproduction Politics in Postwar Poland," in Women and Men at War: A Gender Perspective on World War II and Its Aftermath in Central and Eastern Europe (Osnabrück, 2012) - the conference was held from 31 March to 2 April 2011 in the German Historical Institute in Warsaw.

4 Sylwia Kuźma-Markowska, "Walka z 'babkami' o Zdrowie Kobiet: Medykalizacja Przerywania Ciąży w Polsce w Latach Pięćdziesiątych i Sześćdziesiątych xx Wieku," Polska 1944/45-1989. Studia i Materiaty, 15 (2018): 189-214, https://doi.org/10.12775/Polska.2017.10; Sylwia KuźmaMarkowska, "Marx or Malthus? Population Debates and the Reproductive Politics of StateSocialist Poland in the 1950s and 1960s," The History of the Family, 25 (2020): 576-598, https:// doi.org/10.1080/1081602X.2019.1702889.

5 Barbara Klich-Kluczewska, "Biopolitics and (Non-)Modernity. Population Micro-Policy, Expert Knowledge and Family in Late-Communist Poland," Acta Poloniae Historica, 115 (2017): 151-174, here 151 https://doi.org/10.12775/APH.2017.115.06.

6 Ibid., 173 . 
psychotherapy, including talk therapies. Birthing schools became frequented by expectant mothers and even fathers-to-be, and this was broadly discussed in the press and celebrated as a sign of modernity. ${ }^{7}$ Modernity was a keyword for socialism, which in the realm of marriage manifested itself as a 'culture of sexuality.' Promoted by experts, the 'culture of sexuality' entailed equality between the spouses, rationality in family planning, and psychological health.

What was and was not healthy for women in the realm of reproduction kept being revised by experts throughout state socialism. While abortion was always painted as a potentially dangerous intervention, the historian of medicine Agata Ignaciuk argues that gynecologists provided nuanced arguments from the time of the procedure's legalization and throughout the 196os, only to shift gears after 1970 and present abortion rather straightforwardly as causing infertility. ${ }^{9}$ In the process, women's agency diminished together with the discursive shift in framing abortion from 'social' to 'therapeutic.' Legalizing abortion was terminologically tied to 'social' reasons that led women to opt for pregnancy termination. In the 197os, doctors began to highlight 'therapeutic' cases where the fetus was (suspected to be) malformed. While the debate was blurred by pointing to the 'social' consequences of raising such a child, the therapeutic indication paved the way to a narrowly health-related discourse that led to obscuring a woman's choice in the process. The discourse prepared the ground for the recriminalization of abortion in $1993{ }^{10}$

With abortion legalized, Polish experts embarked on the path of promoting contraception. Women terminating pregnancies were given leaflets about methods preventing conception. In the 1950s, women were advised to use spermicidal creams or cervical caps so that they avoid psychological exhaustion and could enjoy "the atmosphere of joy and harmony returned to their families."11 What joy and harmony meant was specified in 1965 as alleviating "[c]ontinuous fear of pregnancy [which] causes a woman to despise having

7 Klich-Kluczewska, "Biopolitics and (Non-)Modernity."

8 Natalia Jarska, "Modern Marriage and the Culture of Sexuality: Experts between the State and the Church in Poland, 1956-1970," European History Quarterly, 49 (2019): 467-49o, https://doi.org/10.1177/0265691419857552.

9 Agata Ignaciuk, "In Sickness and in Health: Expert Discussions on Abortion Indications, Risks, and Patient-Doctor Relationships in Postwar Poland," Bulletin of the History of Medicine, 95 (2021): 83-112, https://doi.org/10.1353/bhm.2021.00o3.

10 Ibid., 111 .

11 Gynecologist Michalina Wislocka, 1959, quoted in Agata Ignaciuk, "No Man's Land? Gendering Contraception in Family Planning Advice Literature in State-Socialist Poland (1950s-1980s)," Social History of Medicine (6 May 2019): 1327-1349, here 1340, https://doi. org/10.1093/shm/hkzoo7. 
intercourse with her husband."12 In other words, using modern forms of contraception provides for happy sexual unions. Satisfactory marital sexuality was the focus of Polish sexologists, as the anthropologist Agnieszka Kościańska has persuasively shown. ${ }^{13}$ Happiness in marriage was to stem from planning when to have children, and modern contraception was also hailed as preserving a woman's beauty and attractiveness to her husband. Books advising women on contraception also included lengthy sections on maintaining good looks, which too frequent pregnancies and births would spoil. Ignaciuk shows that this warning did not disappear over time; if anything, it began to sound ever more alarming when picturing expectant and new mothers as focusing on the baby and neglecting their appearance and their husband's sexual appetite - to their detriment, when said husbands sought out sex with other women. ${ }^{14}$

Men were also addressed, however sporadically, as co-responsible for preventing an unwanted pregnancy. According to surveys, coitus interruptus, a method completely controlled by the man, was among those most often used in Poland. Man's role of a loving and caring husband was invoked, yet withdrawal was often blamed for the sexual dissatisfaction of both partners. When 'interrupted,' coitus could not have provided the release and relaxation, and in the eyes of experts, spouses became nervous and irritable. Ignaciuk argues that such statements appeared in advice literature repeatedly, yet without scientific evidence. ${ }^{15}$ Curiously, advice on condoms was split between enthusiastic approval and outright rejection. The unfavorable expert opinions "claimed condoms diminished sexual pleasure for both partners, were aesthetically unpleasing and deprived women of the beneficial effect of semen on their bodies"; when preventing venereal disease, only the situations of bachelors having sex with (multiple) women were mentioned as problematic. ${ }^{16}$ Family planning in Poland for the entirety of state socialism remained firmly based on stark gender stereotypes.

The socialist state expressed its priorities by providing state health insurance in rural areas only to women and children; individual (primarily male)

12 Wislocka, 1965, quoted in Ignaciuk, "No Man's Land?" 1340.

13 Agnieszka Kościańska, Gender, Pleasure, and Violence: The Construction of Expert Knowledge of Sexuality in Poland, New Anthropologies of Europe (Bloomington, IN, 2020); Agnieszka Kościańska, "Sex on Equal Terms? Polish Sexology on Women's Emancipation and 'Good Sex' from the 1970s to the Present," Sexualities, 19 (2016): 236-256, https://doi. org/10.1177/1363460714557662; Agnieszka Kościańska, "Beyond Viagra: Sex Therapy in Poland," Czech Sociological Review, 5o (2014): 919-938, here 919, https://doi.org/10.1306o/oo 380288.2014.50.6.148.

14 Ignaciuk, "No Man's Land?".

15 Ibid., 1345 .

16 Ibid. 
farmers remained uninsured until the 1970s. ${ }^{17}$ While 'good' women enjoyed state support, 'bad' women - those seen as prostitutes or as just promiscuous risked internment in venereal wards, sometimes even despite being disease-free. Degrading treatment featuring medically unnecessary procedures happened daily. ${ }^{18}$ Even after oral contraceptives became available, women used them only sporadically; the reason is likely to be found in the state's strong support for abortion. ${ }^{19}$

Hungary legalized abortion in 1953, changing the status quo, which had banned terminating pregnancy across the board, even in cases when a mother's health or life was endangered. Unlike other Eastern Bloc countries, Hungary's birthrate after the war hovered around the reproduction level. Making abortions available sent the rate of childbirth tumbling. ${ }^{20}$ Hungarian women took a particular liking to the procedure: while abortion rates in Poland remained forever low, and while neighboring Czechoslovakia counted one termination per two to three births, the abortion-rate in Hungary was one third higher than the birth-rate. As a result, Hungarian policymakers firmly set a pronatalist path by the end of the 196os, encouraging all women to reproduce by providing universal family allowances, a three-year paid maternity leave, and birth payments. Not only giving birth to children but also raising them became heavily supported by the state. ${ }^{21}$ These child protection policies also aimed at regulating their mothers' sexuality and access to employment. ${ }^{22}$ Historian Eszter Varsa argues that eugenic concepts, such as population quality and healthy birth, continued to shape the Hungarian discourses of family planning long after the war. In the last two decades of state socialism, eugenics manifested as encouraging women with higher education to reproduce ${ }^{23}$ while perpetuating the messages of motherhood as the fulfillment of the woman's role. ${ }^{24}$

17 Ewelina Szpak, "Personal hygiene and public health care in the Polish countryside after 1945 - propaganda against reality," Roczniki Dziejów Spotecznych i Gospodarczych, 79 (2018): 165187, https://doi.org/10.12775/RDSG.2018.o6.

18 Agata Ignaciuk, “'Clueless about Contraception': The Introduction and Circulation of the Contraceptive Pill in State-Socialist Poland (196os-1970s)," Medicina Nei Secoli, 26 (2014): 509-535.

19 Jarska, "Modern Marriage and the Culture of Sexuality."

20 Lynne Haney, Inventing the Needy: Gender and the Politics of Welfare in Hungary (Berkeley, CA, 2002), 92.

21 Haney, Inventing the Needy.

22 Eszter Varsa, "Sex Advice East and West: Sex Education and Family Planning in Cold War Austria and Hungary," The History of the Family, 25 (2020): 649-670, https://doi.org/10.1080/1 o81602X.2019.170289o.

23 Ibid.

24 Eszter Varsa, "Respect Girls as Future Mothers': Sex Education as Family Life Education in State Socialist Hungary (1950s-1980s)," in Children by Choice? Changing Values, Reproduction, 
In Czechoslovakia, abortion was legalized in 1957, and gynecologists exerted considerable influence over the terms in which the debate around abortion was carried out in broader society. As the sociologist Radka Dudová argues, the most prevalent reason was "abortion for a healthier motherhood," as doctors pointed out that botched back-alley abortions might endanger women's health and, with it, their capacity to become mothers in the future. ${ }^{25}$ As my research has shown, women's health indeed played a role - already five years before legalization, when gynecologists strove to decriminalize abortion, they accomplished 'only' the compilation of extensive lists of conditions indicating termination on medical grounds. In 1956, selected hospitals, together with workplaces all across Czechoslovakia, launched a survey of family planning practices, asking women about their choices. The researchers, mostly demographers, were stunned by a high proportion of women, almost 30 per cent, who reported their last pregnancy as unwanted, and an even higher rate of women, 40 per cent, answering 'yes' when asked if they would opt for an abortion if the procedure was legal. "Given the high percentage of unwanted children, the topic of happy parenthood with multiple children emerges," wrote one of the researchers, calling for the legalization of abortion as a "highly logical" step, by which the state "relinquishes this right for the benefit of the female part of its inhabitants." 26 Further, these experts perceived abortion as "consistent with equal rights of women, bringing about truly joyful parenthood, freed from the aspects of unwanted pregnancy."27 Thus, not only maternal health, but women's equality also became part of the legalization debate in this Eastern European country.

\section{Different Actors and Institutions on the Path to Modernity}

As has become clear by now, the role of experts and expertise in socialist states was particularly pronounced. Next to gynecologists and demographers, women's reproductive choices were often managed by sexologists. In

and Family Planning in the 2oth Century, vol. 3 (Berlin-Boston, MA, 2018), 77-98, https://doi. org/10.1515/9783110524499-004.

25 Radka Dudová, "Regulation of Abortion as State-Socialist Governmentality: The Case of Czechoslovakia," Politics and Gender, 8 (2012): 123-144; Radka Dudová, Interrupce v České Republice: Zápas o Ženská Těla (Prague, 2012); Hana Hašková and Radka Dudová, "Selective Pronatalism in Childcare and Reproductive Health Policies in Czechoslovakia," The History of the Family, 25 (2020): 627-648, https://doi.org/10.1080/1081602X.2020.173756.

26 Kučera, 1956, quoted in Kateřina Lišková, Sexual Liberation, Socialist Style: Communist Czechoslovakia and the Science of Desire, 1945-1989 (Cambridge, 2018), 104-105.

27 Kučera, 1956, quoted in Lišková, Sexual Liberation, Socialist Style, 108. 
Czechoslovakia, sexologists gave advice in cases of female infertility, which gynecologists suspected was linked to a lack of orgasm. ${ }^{28}$ At the beginning of the 195os, gynecologists debated the extent to which the woman's climax influenced conception. Medical opinions ranged on the scale from no influence, through some facilitation, to very important. At the same time, infertility became covered by the national health insurance as an illness, and as such, treatment for infertile women also encompassed spa procedures. At a spa specialized in gynecological health, local doctors noticed that among the thousands of treated women, about 9 per cent did not show any somatic problems. Yet, these women complained about deficiencies in their sex lives and blamed their sterility on these shortcomings. Sexologists were invited to weigh in on the issue. They devised a complex survey of 500 women who could not conceive and compared them with a control group of 250 pregnant women. The results clearly pointed to the sexual problems of infertile women: they reported problems in sexual function (about twice as often as the control group) and less frequent orgasms (at about half of the rate compared with the controls). The women complained about the short duration of intercourse and sometimes about the weak potency of their husbands. It confirmed sexologists' suspicion that the mutual accord in sex depended, indeed, on both partners. The chief sexologist Josef Hynie chided men who saw women as less than their equals; such a man who "does not have a sense of equality, if he always needs to feel superior"29 cannot satisfy his wife sexually. While the causal link between the female orgasm and conception was disproved, another causation emerged: that of an egalitarian, loving marriage leading to good sex.

Hungarian sexologists came to the discussion about the female orgasm later than their Czechoslovak counterparts, yet their advice also pivoted around the nuclear family and how to preserve it. ${ }^{30}$ In the 196os, debates began to stir about the future of monogamous marriage. Indeed, Hungarian divorce rates in the 1950s were already the highest in the Eastern Bloc, and the upward trend was unrelenting. Some philosophers began publicly discussing the consistency of socialist marriage with the "fetish of sexual fidelity" and the "strict demands of tradition." These fringe voices began resonating in the mainstream by the end of the following decade when a marriage manual by a well-known and widely respected sexologist Vilmos Szilágyi was published in 1978. In the book

28 Lišková, Sexual Liberation, Socialist Style, 122-156.

29 Hynie, 1948, quoted in Lišková, 132.

30 Kateřina Lišková and Gábor Szegedi, "Sex and Gender Norms in Marriage: Comparing Expert Advice in Socialist Czechoslovakia and Hungary between the 1950s and 1980s," History of Psychology, 24 (2021): 77-99, https://doi.org/10.1037/hopoooo179. 
titled The Future of Marriage, the author decried patriarchal marriage with its rigid gender roles and proposed that society "give up the concept of sexual exclusivity." Stunningly, the reviews published in the popular press praised the book and embraced sexual freedom "as a scientifically grounded principle." Participants in television debates contended that human fidelity meant much more than sexual fidelity, and allowing extramarital relationships would not increase divorce rates or dissolve the family institution. Proponents equated their takes on open marriage with debates around legalizing abortion some fifteen years earlier: however profound these changes might seem to ordinary people, both are inevitable milestones on the path to modernization.

In Poland, sexologists were medical doctors who were inspired by the approaches of the social sciences and the humanities, so they viewed sex holistically as enmeshed in social and cultural settings and interpersonal relationships. They drew heavily on their clinical practice and feedback from their patients and readers of their books and magazine columns. Kościańska, in her analysis of varied sources - including expert writings and patients' letters excels in documenting how pervasive sexological advice was in creating the sexual selves of Poles during socialism. ${ }^{31}$ Sexologists advised on married sex, focusing on female pleasure and perceiving masturbation as good for women, including stimulating the clitoris during intercourse. Significantly, sexological views influenced women who gradually stopped being ashamed if they could only climax clitorally and, empowered by sexological accounts of the normalcy of clitoral orgasm, even demanded clitoral stimulation during sex with their husbands. Yet, sexologists' often forward-looking stances on sex did not necessarily go hand in hand with gender progressiveness. More often than not, Polish sexologists underscored good sex by gender-hierarchical relationships within marriage and posited intercourse as the proper aim and culmination of the sexual act. Most tragically, gender stereotypes about sexually provocative women, and men who could not control their hormonally driven impulses, were mobilized by experts when assessing rape cases.

In all the discussed Eastern European countries, sexology developed in conversation with various state actors, its research and clinical practice being financed exclusively by the state (as was the only option in state-socialist command economies). Yet, the topics these medical doctors studied were largely shaped without state meddling. During socialism, the tenets of sexology were formed by "years outside the influence of the market - away from erotica, pornography, and the 'pursuit of orgasm' so omnipresent today, and instead

$31 \quad$ Agnieszka Kościańska, Pteć, przyjemność i przemoc: ksztaltowanie wiedzy eksperckiej o seksualności w Polsce, 2014; Kościańska, Gender, Pleasure, and Violence. 
with emphasis on relationships and sociocultural conditions," as Kościanska observed of Poland. ${ }^{32}$

Some recent studies of medical practices in Czechoslovakia underscore its intricate relationship to the Soviet Union. With the example of the psychoprophylactic method for painless childbirth, the social anthropologist Ema Hrešanová shows how the practice was introduced in Czechoslovakia in the early 1950s as "Soviet science's gift to women." ${ }^{33}$ A highly praised method, supposedly relieving women of labor pain in 96 per cent of cases, proved less than successful in Czechoslovakia. Local doctors, apparently unsure how to label a failed method that had come from Moscow, blamed a different "psychology of Czech women" and "the different way maternal care is organized in our country."34 Alternatively, the leading proponent of the method in Prague reproached his colleague-obstetricians for their lax attitude when training expectant mothers in preparation for birth. While these efforts might seem quixotic, Hrešanová notes the emphasis gynecologists in the 195os placed on "the importance of building a new socialist society by transforming society's view of the inevitability of pain in childbirth." ${ }^{35}$ The method of painless childbirth was revived in the late 1970s when a midwife devised a study for her degree thesis, in which she compared a group of expectant mothers who underwent the training with a group that went into labour without the training. She found that the trained women experienced significantly shorter labor, which the midwife attributed to their increased self-knowledge and belief in themselves. Based on this study, the midwife organized the course in several healthcare facilities in Prague, and the training became hugely popular, flourishing over the following decade. The psychoprophylactic method thus found a new use in the 1980s when some maternity hospitals began experimenting with alternative methods of childbirth, outside of the factory-like conditions in regular maternity care. Moreover, references to the psychoprophylactic method for painless childbirth were also included in sexual education for children. ${ }^{36}$

32 Kościańska, Gender, Pleasure, and Violence, 228.

33 Ema Hrešanová, "The Psychoprophylactic Method of Painless Childbirth in Socialist Czechoslovakia: From State Propaganda to Activism of Enthusiasts," Medical History, 6o (2016): 534-556, https://doi.org/10.1017/mdh.2016.59. Gynecologist Vojta, 1953, quoted in Hrešanová, "The Psychoprophylactic Method of Painless Childbirth," 540-541.

35 Hrešanová, "The Psychoprophylactic Method of Painless Childbirth," 545.

36 Ema Hrešanová and Paula A. Michaels, "Socialist Science Across Borders: Investigating Pain in Soviet and Czechoslovakian Maternity Care," Revue d'études comparatives Est-Ouest, no. 1 (2018): 45-69, https://doi.org/10.3917/receo1.491.oo45; Ema Hrešanová, "The Island of 
A relationship between the Czechoslovak state and medical sexology, especially in treating sexual deviance, marked a different trajectory. During the first two decades of state socialism, the interest of sexologists or the state in sexual 'perversions' was minimal. In the mid-197os, as part of the institutionalization of medical sexology as a discipline, new wards in psychiatric hospitals were opened for sexual deviants. Courts ordered that men who committed (violent) sexual crimes be detained in these wards. ${ }^{37}$ At first, there were no treatment protocols, and specialized care was developed by trial and error. By the end of the decade, surgical castration became established as a reliable method. Indeed, removing sex glands dramatically and permanently decreases the hormonal levels in deviant males, thus all but ensuring that they will not commit another sex crime. The treatment was developed with the state's endorsement, and was made possible by subsequent ministerial directives on the protective treatment of sexual delinquents and pathological sexual aggressors. My work in collaboration with the sociologist Andrea Bělehradová has shown that the ties between the state and this medical discipline spanned the regime change in 1989 and continue to this day. As a result, the Czech Republic is among a handful of countries practicing this form of intervention, which many international human rights agencies have decried as inhumane. Despite this pressure, Czech sexologists are undeterred, and the Czech ministry of health backs their ongoing practice. ${ }^{38}$

Next to the state, one of the most interesting actors in state socialism was the Catholic Church, an institution widely seen as restrictive when it comes to reproduction and the ways of controlling it. Paradoxically, the Church was the main driving force for free and unlimited access to abortion in Poland. After the state legalized the procedure in 1956 , experts began voicing their concerns about the potentially detrimental consequences that repeated abortions could have on women; the state should instead invest in developing safe, modern contraception and steer women to 'conscious motherhood.' Yet, the state officials dug their heels in: abortion was declared a modern way to control fertility, and plans to produce contraceptives were halted. The state's policy was

Alternatives: Power, Medical Science, and 'Gentle Birthing' in Socialist Czechoslovakia,” Journal of the History of Medicine and Allied Sciences, 73 (2018): 73-95, https://doi.org/10.1093/ jhmas/jrxo56.

37 Kateřina Lišková, “'Now You See Them, Now You Don't': Sexual Deviants and Sexological Expertise in Communist Czechoslovakia," History of the Human Sciences, 29 (2016): 49-74, https://doi.org/10.1177/0952695115617383.

38 Kateřina Lišková and Andrea Bělehradová, “'We Won't Ban Castrating Pervs Despite What Europe Might Think!': Czech Medical Sexology and the Practice of Therapeutic Castration," Medical History, 63 (2019): 330-351, https://doi.org/10.1017/mdh.2019.30. 
formulated in clear opposition to the Church and served as a battle in the war socialism had declared on religion. ${ }^{39}$ However, this state-church antagonism eased over the decades. In 1986, a new state-approved sex education textbook, which presented homosexuality as an innocuous variant of human sexuality and was generally very open in discussing sex with schoolchildren, was scrapped a mere three months after publication, in response to Catholic discontent. ${ }^{40}$

In the context of the Church's intransigence in questions of sexual freedom, the instances of Catholic progressiveness when approaching reproduction are all but forgotten. In fascinating detail, Agnieszka Kościańska documents the disproportionate influence that one female psychiatrist wielded over the future Pope John Paul II. In Warsaw, forward-looking Catholic intellectuals "opined [that] most morally justified methods of birth control were not those most 'natural," that is, periodic abstinence, but rather those that made sex "less routine, free from fears [of unwanted pregnancy] and accessible to all."41 With these pleas, they aimed to influence the encyclical Humanae vitae that was in the making. Yet, much more conservative circles existed in Krakow and Lublin where Karol Wojtyła, the future pope John Paul II, delivered a series of lectures as a part-time teacher of philosophy. For his friend and confidante, a psychiatrist Wanda Półtawska, sex that was not open to procreation undermined dignity, which led to abuses, especially abuses of women by men. Półtawska, who survived Ravensbrück, was among those from Wojtyła's circles who first called contraception and abortion "the civilization of death" and compared them to the Nazi death camps. She influenced Wojtyła's writing on Love and Responsibility, which was published as early as 196o. Moreover, Kościańska argues that "Półtawska's influence on his views perhaps extended so far as her (ghost) co-authoring his contributions to the encyclical."42 The Church offered unexpected fuel to progressive change (when the state fought to provide a counterbalance to the Church-backed traditionalism), and proved to be an incubator of certain liberalizing ideas (for married believers on how to live their intimate lives); in this it acted simultaneously as a progressive circuit-breaker and as a guardian of conventional ways of living.

39 Jarska, "Modern Marriage and the Culture of Sexuality."

40 Agnieszka Kościańska, To See a Moose: The History of Polish Sex Education, English-language edition, European Anthropology in Translation, vol. 9 (New York, 2021).

41 Kościańska, "Humanae Vitae, Birth Control and the Forgotten History of the Catholic Church in Poland," 191.

42 Kościańska, "Humanae Vitae, Birth Control and the Forgotten History of the Catholic Church in Poland," 195. 
Taking up a specific praxis, such as gendered and sexual medicine, to illustrate the state of the history of medicine in Eastern Europe comes with unavoidable limitations. Clearly, the studies, which do not set gender as their analytical tool or those that ignore sexuality and reproduction, slip from view. That is not to say that such studies do not exist. But limiting the scope of this paper, I believe, brings out the richness of the research that has recently emerged. This research is solidly based in local archives, and its authors put their findings in conversation with their international colleagues, contributing to ongoing intellectual exchanges.

Thanks to the studies cited here, we learn that reproductive rights mark a different timeline in Eastern Europe, granting women the freedom to make decisions about their pregnancies some two decades before abortion was legalized in Western Europe. Many have argued that abortion was, in fact, used as a form of contraception in the East, mainly because the pill became available later and in a more limited way than access to the legal termination of pregnancy. The studies also show that, before 1989, the pill never reigned supreme among modern contraceptives: that place belonged to the intrauterine device. Interestingly, family planning was wrapped in discourses of modernization and a 'culture of sexuality', and the condition of infertility was thoroughly researched and connected with the quest for female sexual pleasure. While gender stereotypes did not vanish by any stretch of the imagination, medical doctors and other experts brought women's equality up time and again as intrinsically tied to the new treatments, e.g., (in)fertility, and approaches to, e.g., divorce and the family.

Entanglements between medicine and other institutions often took an unexpected shape. Surprisingly, the state was not implicated as heavily as one might expect, given the authoritarian context, and physicians set their research agendas and treatment protocols based on the 'realities on the ground.' The medical establishment in Czechoslovakia, on the one hand, carefully unaligned itself from the state (and more so, the 'superstate' that was the USSR) in the case of a failing psychoprophylactic method of painless childbirth and, on the other hand, coordinated with the state in the case of the surgical interventions performed on sexual deviants. The skirmishes between the state and the Catholic Church in Poland fueled the early and unrestricted access to abortion, and when the ideological fights waned, the liberal approaches weakened, first in school-based sex education and later in regard to abortion access.

These histories show that it is not only trained historians of medicine who write them. Among our authors, we also find anthropologists and sociologists. 
I suggest that this diversity introduces new angles and brings forth new stories. In any case, there is a growing interest in hearing these stories. While most of the papers cited here were published in English, there is a wealth of histories written in national languages, and it is high time that we lend our ears to them.

Years ago, as a graduate student and an early career researcher, I would hear that Eastern Europe is of no interest to the West (and by extension of no interest to anyone else). Gone was the 199os heyday when international scholars were curious about what comes out of the rubble of the Berlin Wall. In the new millennium, nobody cared about this region anymore. Westerners were painted as the only true scholars, setting the tone and research agendas. 'They,' it was said repeatedly, only want 'us' to provide raw data, which will illustrate 'their' grand theories. I do not want to dismiss colonialism in science - it certainly does exist and makes its influence felt. My aim here is to argue that the present situation is not so bleak. Most scholars of Eastern Europe come from the region, yet they are fully integrated into international debates. The fascinating findings do come from within. They are reaching their readers and interlocutors. ${ }^{43}$ The very foundation of this journal attests to the growing interest in this dialogue, on the European level and beyond.

43 Stemming out of this renewed scholarly interest is also my new comparative research into histories of maternal health and childhood normality, entitled "Expertise in authoritarian societies: Human sciences in the socialist countries of East-Central Europe." I would like to thank the Czech Science Foundation for their generous support, granted under the EXPRO scheme (21-28766X). 